\title{
Toll-like receptors activation, signaling, and targeting: an overview
}

\author{
Salwa Refat El-Zayat ${ }^{*}$ (D), Hiba Sibaii(D) and Fathia A. Mannaa
}

\begin{abstract}
Background: Toll-like receptors (TLRs) are an important family of receptors that constitute the first line of defense system against microbes. They can recognize both invading pathogens and endogenous danger molecules released from dying cells and damaged tissues and play a key role in linking innate and adaptive immunity. TLRs are widely distributed in both immune and other body cells. The expressions and locations of TLRs are regulated in response to specific molecules derived from pathogens or damaged host cells. The binding of ligands to TLR activates specific intracellular signaling cascades that initiate host defense reactions. Such binding is liganddependent and cell type-dependent and leads to production of pro-inflammatory cytokines and type 1 interferon. TLR-dependent signaling pathways are tightly increased during innate immune responses by a variety of negative regulators. Overactivation of TLRs can ultimately lead to disruption of immune homeostasis and thus increase the risk for inflammatory diseases and autoimmune disorders. Antagonists/inhibitors targeting the TLR signaling pathways have emerged as novel therapeutics to treat these diseases.

Aim of work: The present review summarizes the structure, characterizations, and signaling of TLRs and their regulators, as well as describes the implication of TLRs in many diseases with a brief idea about the inhibitors that target TLR signaling pathways.

Conclusion: We conclude that TLRs are the main elements of our immune system, and they should be maintained functioning to keep the integrity of innate immunity. Targeting of TLR signaling represents a new challenge for treatment of many diseases.
\end{abstract}

Keywords: Toll-like receptors, Innate immunity, TLR signaling, Feedback regulators, Antagonists/inhibitors

\section{Background}

The innate immune system provides an immediate defense mechanism upon damage or pathogen invasion, which allows the adaptive immune system to initiate an antigen-specific response. Short-term activation of the innate immune system is beneficial and provides cytoprotective mechanisms for tissue repair. However, sustained or excessive immune system activation is deleterious and leads to irreversible changes in organ structure and function (Wang et al., 2015). Toll-like receptors (TLRs) is a family of pattern recognition receptors (PRRs) that form the cornerstone of the innate immune response (Sadik et al., 2015). Toll was originally discovered as a gene controlling the dorsal-ventral polarity of the Drosophila embryo, but was later found to be involved in anti-fungal

\footnotetext{
* Correspondence: salwarefat@gmail.com

Medical Physiology Department, Medical Division, National Research Centre, 33 El-Bohouth Street, Dokki, POB:12311, Cairo, Egypt
}

immunity (Anderson et al., 1985). The innate immune system gained its importance by the discovery of these receptors (Brikos \& O'Neill, 2008). To date, 10 human and 13 murine subtypes of TLR have been identified, although TLR10 is non-functional in the mouse (Wang et al., 2015). They can recognize both the external pathogen-associated molecular patterns (PAMPs) (Zhang \& Liang, 2016) and the internal damage-associated molecular patterns (DAMPs) (Yu \& Feng, 2018). They are expressed on all innate immune cells such as macrophage, neutrophils, dendritic cells (DCs), natural killer (NK) cells, mast cells, basophils, and eosinophil (Delneste et al., 2007). TLR activation stimulates signaling cascades by the host as a defense mechanism against invaders and to repair the damaged tissue (Wang et al., 2015), leading to the release of various inflammatory cytokines and immune modulators (Wong et al., 2009). Excessive TLR activation disrupts the immune homeostasis by sustained pro-inflammatory 
cytokines and chemokine production and consequently contributes to the development and progression of many diseases (Komurcu et al., 2016), such as autoimmune diseases including lupus erythematous (Subramanian et al., 2006) and rheumatoid arthritis (Huang \& Pope, 2009), cancer (So \& Ouchi, 2010), sepsis (Tsujimoto et al., 2008), Alzheimer's disease (Zhang et al., 2011), and diabetes type 1 (Jialal et al., 2015). A variety of regulatory factors that control TLR activation have been reported to be involved in the negative feedback of TLR-dependent signaling (Yuk \& Jo, 2011). In addition, antagonists/inhibitors targeting TLR signaling represent a potential method for the therapeutic strategy (Gao et al., 2017). The current review describes the structure, characterizations, and signaling of TLRs, feedback regulators of TLR signaling, and the inhibitors that target TLR signaling pathway.

\section{Pattern recognition receptors (PRRs)}

Microbes generate a vast array of PAMPs, which can be recognized by cells of the innate immune system (Zhang \& Liang, 2016). This recognition of "non-self" signs occurs via host PRRs, suggesting that the microbial-derived signals are good targets for innate immunity to discriminate between self- and non-self (Dolasia et al., 2018). Sensing of these pathogens occurs instantly and effectively, inducing suitable immune response (Kawai \& Akira, 2011). Toll-like receptors (TLRs) belong to PRRs, and they are crucial in host protection against microbial infections as they generate innate immune response (Vidya et al., 2017). They recognize both PAMPs and DAMPs derived from tissue damage (Yu \& Feng, 2018; Gauthier et al., 2010). The ligands for TLR are extremely broad, ranging from hydrophilic nucleic acids to hydrophobic lipids and from small-sized compounds to macromolecules (Wang et al., 2015).

\section{Discovery of TLRs}

TLRs received their name from their similarity to the protein coded by the toll gene identified during the embryonic development and dorsoventral polarization of Drosophila in 1985 by Christiane Nüsslein-Volhard. She saw a strange phenotype in mutant fly larvae and exclaimed, "Das war ja toll!" which in German means "That was strange or weird!"; hence, the name "Toll" was given to the protein (Anderson et al., 1985). It was discovered that the protein encoded by "Toll" gene serves as a receptor on cells (Schneider et al., 1991), and this protein was essential for the host innate immunity against fungal infection in adult flies (Lemaitre et al., 1996).

\section{Structure and characterization of TLRs}

TLRs are type I transmembrane proteins with 20-27 extracellular leucine-rich repeats (LRR) for the recognition of PAMP/DAMP, transmembrane domains, and intracellular toll-interleukin 1 (IL-1) receptor (TIR) domains required for the activation of downstream signal transduction pathways (Fig. 1) (Gao et al., 2017). The extracellular domains of TLR contain glycan moieties that serve as binding sites for ligands (Akira et al., 2006). However, the exact mechanisms underlying glycan-mediated recognition of ligands are not clear (Isaza-Correa et al., 2014). The main characteristics that distinguish different TLRs are ligand specificity, signal transduction pathways, and subcellular localization (Singh et al., 2014) .

\section{Members of TLR family}

Ten members of the human )Fig. 2) (Mahla, 2013) and 13 members of the mouse TLR family have been identified, although TLR10 is non-functional in mouse (Yamamoto \& Takeda, 2010). TLR4 was the first toll protein homolog discovered in humans, it was shown to induce expression of genes involved in inflammatory responses (Medzhitov et al., 1997), and its role was confirmed when the point mutation in the TLR4 gene was identified in a mouse strain that was unresponsive to lipopolysaccharides (LPS) (Poltorak et al., 1998). TLRs are functionally subdivided into:

I. Cell membrane TLRs (heterodimers of TLR2 with TLR1 and TLR6 in addition to TLR4, TLR5, and TLR10) that are expressed on the cell surface (Gay et al., 2014).

II. Intracellular TLRs or nucleic acids sensors (TLR3, TLR7, TLR8, and TLR9) that are localized to endoplasmic reticulum (ER), endosomes, and lysosomes (Sellge \& Kufer, 2015).

\section{Expression of TLRs}

It is amazing that the expression of TLR mRNA are not restricted to immune tissues like the spleen, thymus, tonsils, lymphatic vessels, and lymph nodes but distributed in all tissues including the peripheral blood leukocytes, heart, liver, pancreas, colon, small intestine, lung, kidney, ovary, placenta, testis, prostate, skeletal muscle, and brain (Zarember \& Godowski, 2002). They are expressed on all innate immune cells including macrophages, NK cells, DCs, and circulating leukocytes such as monocytes and neutrophils as well as on adaptive immune cells like $\mathrm{T}$ and $\mathrm{B}$ lymphocytes and on non-immune cells like epithelial and endothelial cells and fibroblasts (Delneste et al., 2007).

\section{Exogenous ligands of TLRs}

PAMPs include microbial molecular structures (Fig. 3) (Hemmi et al., 2000) such as proteins (e.g., flagellin from bacterial flagella), lipoteichoic acid (LTA) and peptidoglycan (PGN) from Gram-positive bacteria, LPS from Gramnegative bacteria, lipoarabinomannan (LAM), lipopeptides, lipoglycans, and lipomannans from mycobacteria, zymosan from yeast, double-stranded (ds) RNA of viruses, and DNA 


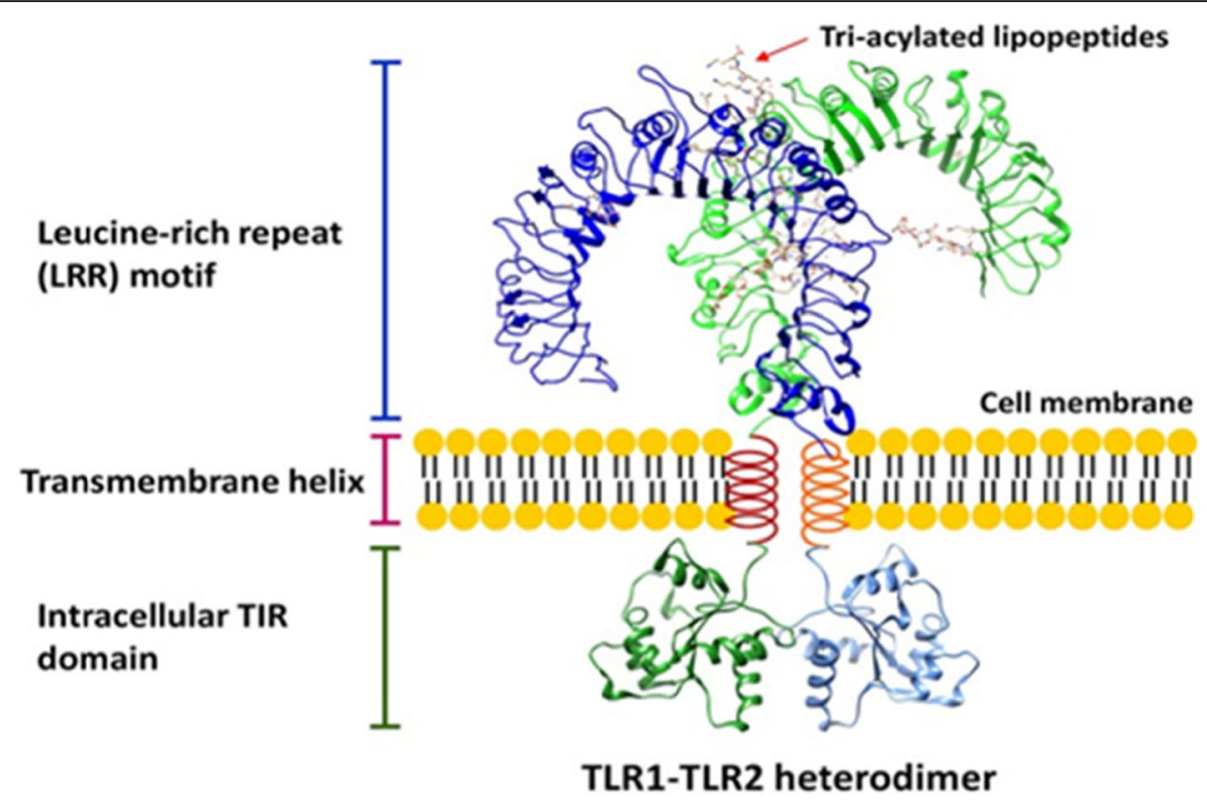

Fig. 1 Structure of TLRs

from viruses and bacteria (Hoebe et al., 2003; Ayres \& Schneider, 2012).

\section{Endogenous ligands of TLRs}

Endogenous ligands or host-derived DAMPs (Fig. 3) (Hemmi et al., 2000) are usually produced as a result of injury and non-physiological cell death, including extracellular matrix components (e.g., hyaluronan and fibrinogen), plasma membrane constituents, nuclear and cytosolic proteins [e.g., high-mobility group box protein 1 (HMGB1) and heat shock proteins (HSPs)], and elements of damaged/fragmented organelles [e.g., mitochondrial DNA (mtDNA)] (Murad, 2014).

\section{Adaptor proteins for TLR signaling}

In mammals, five different types of signaling adaptor proteins can be recruited by the TIR domain (Akira \& Takeda, 2004):

- Myeloid differentiation primary-response protein 88 (MyD88).

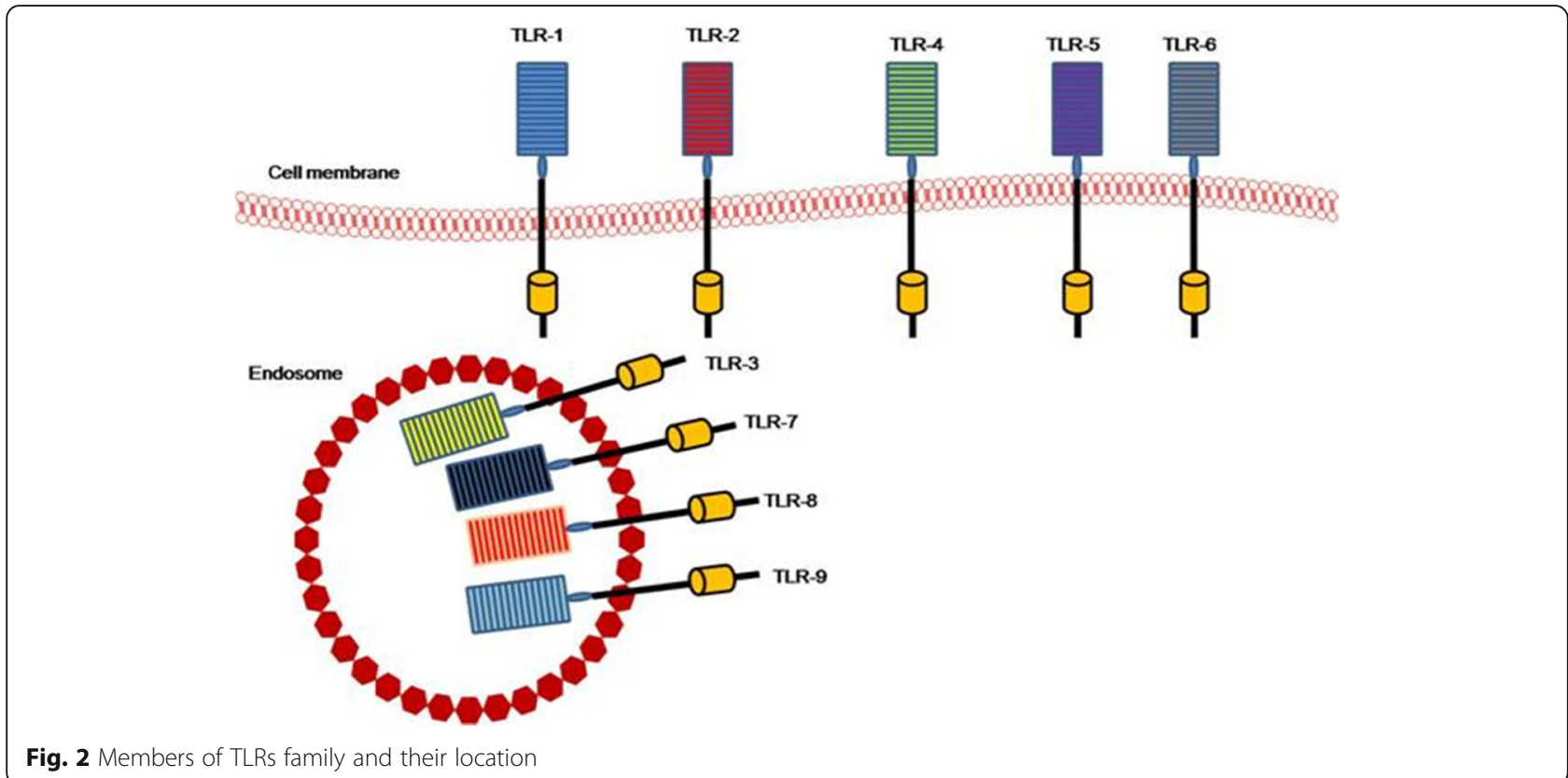




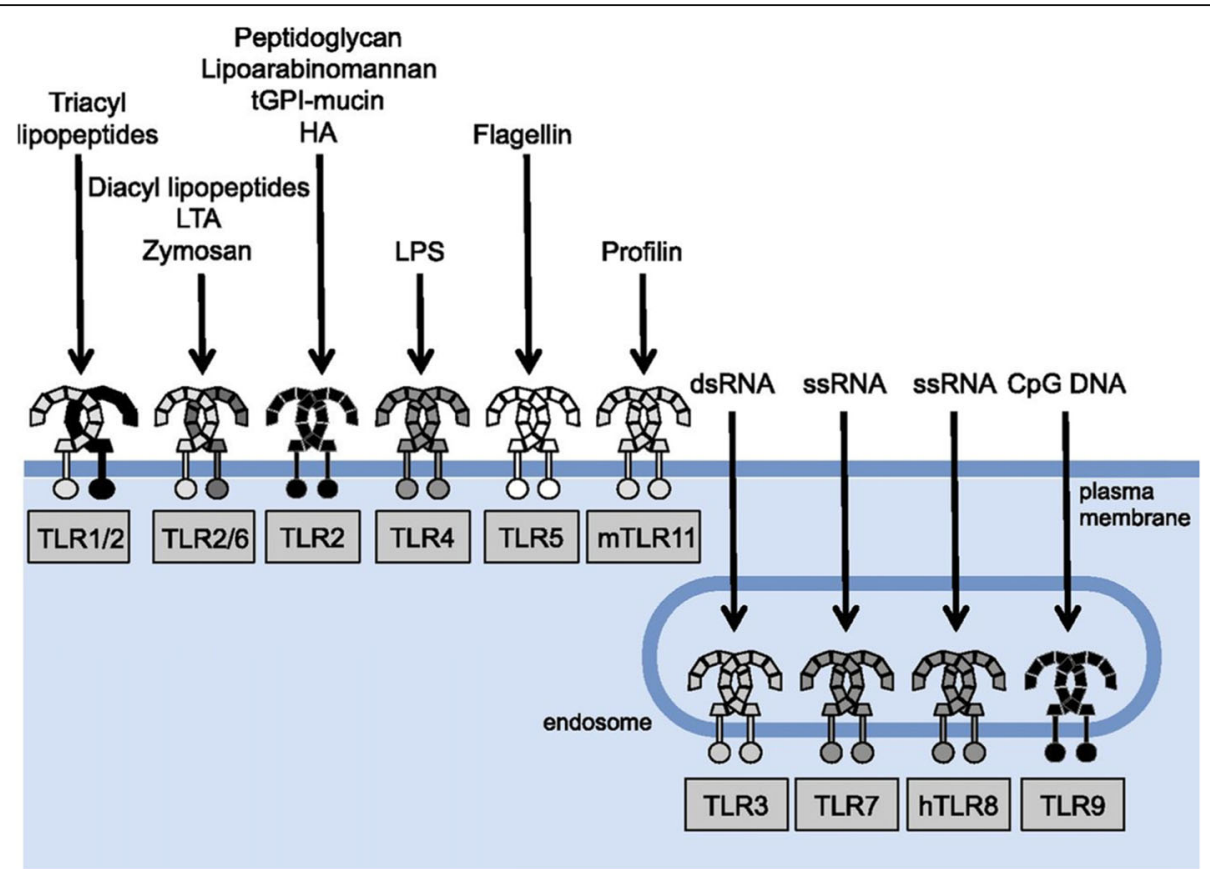

Fig. 3 PAMPs and DAMPs as stimulators of TLRs

- TIR domain-containing adaptor protein (TIRAP or MAL).

- TIR domain-containing adaptor protein inducing IFN- $\beta$ (TRIF).

- TRIF-related adaptor molecule (TRAM).

- Sterile $\alpha$ - and armadillo-motif-containing protein (SARM).

The MyD88 signaling cascade is essential for TLR2, 4, $5,7,8$, and 9 (Burns et al., 2003). TIRAP activation is MyD88-dependent and is associated with TLR2 and 4 (Mansell et al., 2004; Bernard \& O'Neill, 2013). TRIF acts independently of MyD88 in signal transduction following TLR3 and 4 activation (Cusson-Hermance et al., 2005; Bryant et al., 2015). TRAM mediates TLR4 signaling in a MyD88-independent/TRIF-dependent way (McGettrick et al., 2006). SARM is a negative regulator of TRIF and therefore serves to regulate TLR3 and 4 signaling (Couillault et al., 2004; Troutman et al., 2012).

\section{Signaling pathways of TLRs}

The binding of ligands to TLR stimulates specific intracellular downstream signaling cascades that initiate host defense reactions (Wang et al., 2015). Such PAMP-PRR interactions lead to production of pro-inflammatory cytokines and type 1 interferon that orient immune responses to particular microbes (Zhang \& Liang, 2016). TLR signaling depends on the nature of the stimulus, the activated TLR, and the downstream adaptor molecule. TLR signaling includes at least two distinct pathways (Fig. 4) (Kagan, 2012):
- MyD88-dependent pathway utilized by all TLRs, except TLR3, leading to the production of inflammatory cytokines (Yamamoto et al., 2002).

- TRIF-dependent pathway utilized by TLR3 and 4 and associated with the stimulation of interferon type-1 (Kawai \& Akira, 2010).

\section{Function of TLRs}

The main function of TLRs is the ability to recognize numerous pathogens (Gao et al., 2017). Each cell of immune system contains a specific group of TLR that exert special functions in recognizing PAMP/DAMP and mediating immune responses (Lancaster et al., 2005; Cole et al., 2010). TLR function in innate immunity is through the induction of antimicrobial activity and the production of inflammatory cytokines (Vidya et al., 2017; Li et al., 2010). Upon activation by PAMPs or DAMPs, TLRs recruit adapter proteins that act as a platform to recruit IL-1R-associated protein kinases (IRAK) 1, 2, 4, and M and TAB2 and TNF receptor-associated factor 6 (TRAF6) which finally leads to nuclear translocation of pro-inflammatory transcription factor, nuclear factor kappa-B (NF-kB) (Li et al., 2010; Kumar et al., 2011), activator protein 1 (AP-1) (Gay et al., 2014), and interferon regulatory factor 3 (IRF3) (Zhao et al., 2015). Each transcription factor is responsible for the transcription of specific genes that encodes different set of proteins such as pro-inflammatory cytokines [tumor necrosis factor alpha (TNF- $\alpha$ ), interleukin (IL)- $1 \beta$ and IL-6] and type 1 interferon (IFN- $\alpha, \beta)$, chemokines (CXCL8 and CXCL10), and antimicrobial peptides (Moresco et al., 2011). 


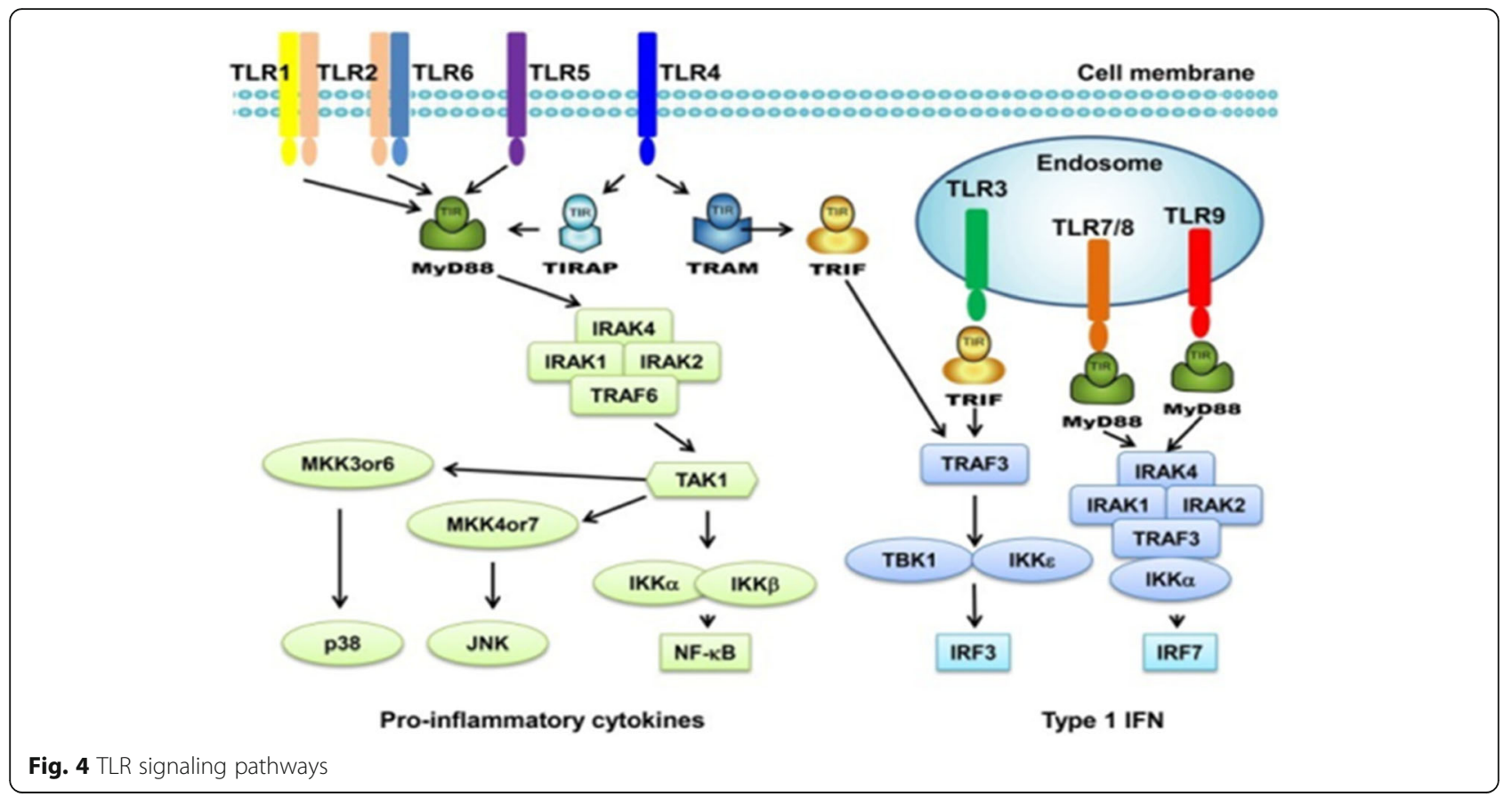

\section{Consequences of the released cytokines}

A major feature of TLRs activation is the secretion of proinflammatory cytokines and type1 interferon. Cytokines are short-lived, long-range mediators that act on different tissues to mount the systemic response. Although TLRs are playing important role in host defense, proinflammatory cytokines such as TNF- $\alpha$ and IL-1 $\beta$ have varied effects on the host body where they are the master contributors for the behavioral changes during infection such as weakness, lethargy, fatigue, and anorexia (Jaffer et al., 2010). They affect the physiological processes as they direct the metabolic processes towards catabolism, preventing muscle protein synthesis, boosting muscle wasting, and inducing liver anabolism. They induce also peripheral lipolysis, upregulate de novo fatty acids synthesis and hepatic triglyceride production, and promote secretion of VLDL-cholesterol, all of which increase serum triglycerides levels (Bresnahan \& Tanumihardjo, 2014).

\section{Importance of TLRs}

- TLRs are bridging molecules since they are expressed on DCs that join innate and adaptive immunity (Gao et al., 2017). TLRs recognize the pathogen and convey the signal to antigen presenting cells which kill the microbes by phagocytosis (Moresco et al., 2011; Sharma et al., 2013). It is worth to note that the presence of a total group of TLRs on immature DCs assists in their maturation process (Re \& Strominger, 2011).
- They received their importance from their ability to recognize invading pathogens, PAMP and endogenous damage molecules DAMP to trigger the process of self-healing and tissue repair (Goulopoulou et al., 2016). The importance of TLR1, 2, and 6 lies in their ability to recognize bacterial lipoproteins and glycolipids (Kawai \& Akira, 2010), TLR7, 8, and 9 identify nucleic acids such as bacterial and viral (ssRNA and unmethylated CpG DNA motif), TLR3 distinguishes viral dsRNA (Takeda et al., 2004), TLR4 recognizes fibronectin and LPS (Blasius \& Beutler, 2010), TLR5 identifies bacterial flagellin, TLR11 and 12 recognize profilin, and TLR10 is still unknown (Takeda \& Akira, 2015).

- TLRs stimulate apoptosis of infected cells. It stop its protein synthesis, limit the infection, and downregulate the immune response as in DCs during the inflammatory conditions of sepsis (Kaiser \& Offermann, 2005).

- TLRs are important risk factors in the pathogenesis of many diseases and the signaling modulation was suggested in disease control and therapy (Tsujimoto et al., 2008). For example, TLR3, 7, and 8 have important roles in the recognition of allergens and subsequently pathogenesis of allergic diseases as allergic rhinitis (Golshiri-Isfahani et al., 2018).

\section{Implication of TLRs in diseases}

Several studies have presented considerable evidences on the contribution of TLR signaling dysregulation to the development and progression of numerous diseases such 
as autoimmune, chronic inflammatory, and infectious diseases as well as cancer (Huang \& Pope, 2009; Jialal et al., 2015; Gao et al., 2017; Isaza-Correa et al., 2014; Devaraj et al., 2011).

\section{Autoimmune diseases}

Systemic lupus erythematous (SLE)

It has been demonstrated that endosomal TLR7 and 9 are found to be overexpressed in SLE associated with the production of autoantibodies (Subramanian et al., 2006); in addition, their levels were found to be correlated with the production of IFN- $\alpha$ (Lyn-Cook et al., 2014). Membrane TLR2 and 4 have been found to be involved in the pathogenesis of SLE (Lee et al., 2016).

\section{Rheumatoid arthritis (RA)}

Bacterial DNA was detected in the joints of patients with RA leading to increased synovial inflammation via TLR signaling (Heijden et al., 1998). TLR2 and 4 are expressed by cells within inflamed joints of patients with RA (Huang \& Pope, 2009). In addition, endogenous TLR3 and 7 were expressed in the synovial tissues of RA (Radstake et al., 2004; Roelofst et al., 2005).

\section{Behcet's disease}

Increased expression of TLR2 and 4 on monocytes of active Behcet's disease patients have been observed (Devaraj et al., 2011; Do et al., 2008).

\section{Chronic hepatitis B virus (HBV)}

The relation between the chronic HBV infection and the expressions of TLR2 and TLR4 was studied (Lu et al., 2014); the authors suggested that the elevated expressions of TLR2 and TLR4 on DCs surfaces in peripheral blood may synergistically promote the disease progression of chronic HBV infection.

\section{Cancer}

Upregulation of some TLRs has been shown in many tumor cells, tissues, and tumor cell lines. TLR1, 2, 3, and 4 were reported to be implicated in colon cancer, TLR2, $3,4,6$, and 9 were shown to contribute to hepatocellular carcinoma, and TLR3, 4, and 9 were shown to be highly expressed in breast cancer (So \& Ouchi, 2010; IsazaCorrea et al., 2014).

\section{Vascular system disorders}

TLRs can recognize circulating DAMPs released from the dying cells and damaged tissues to trigger the process of self-healing and tissue repair (Gauthier et al., 2010). In atherosclerosis, TLR2 or 4 suppression resulted in diminishing inflammation in mouse models of atherosclerosis. TLR3 activation has been found to promote atherogenic inflammation, especially in mediating plaque instability (Ishibashi et al., 2013). In hypertension, TLR4 has been well-documented to mediate inflammation in vasculature (McCarthy et al., 2015).

\section{Sepsis}

Excessive TLR activation can lead to systemic inflammation, characterized as sepsis. TLR2 and 4 are the two sponsors to the pathogenesis of sepsis. Activation of TLRs was also reported to contribute to the development and progression of atherosclerosis, cardiac dysfunction, and congestive heart failure in sepsis (Tsujimoto et al., 2008).

\section{Alzheimer's disease}

A study on Alzheimer's patients has shown a noticeable elevation in TLR2 and 4 expression in the peripheral blood mononuclear cells in late-onset Alzheimer's disease patients (Zhang et al., 2011).

\section{Obesity and type 2 diabetes mellitus (T2DM)}

Obesity and T2DM are known to be associated with chronic low-grade inflammation called metabolic inflammation together with an oxidative stress milieu found in the expanding adipose tissue (Donath et al., 2011). Several DAMPs are released during T2DM; TLR2 activates innate immunity upon recognition of DAMPs. Therefore, TLR2 is significantly involved in diabetes progression (Sepehri et al., 2016). TLR4 signaling pathway is involved in chronic inflammation and insulin resistance, which are associated with obesity and T2DM (Jialal et al., 2015). TLR2 and TLR4 have emerged as metabolic sensors of LPS and sFFAs in obese/T2DM individuals (Ahmad et al., 2012). ROSmediated oxidative stress could induce TLR10 expression via NF- $\mathrm{kB} / \mathrm{MAPK}$ signaling as well as ER stress. Thus, TLR10 may represent an immune marker for metabolic inflammation (Sindhu et al., 2018). The role of inflammation in $\beta$-cell dysfunction in diabetic patients could be related through the strong link between TLRs and both inflammation (Karaali et al., 2019) and autophagy (Yin et al., 2014). The expression of TLR-2 was upregulated in obese/T2DM patients and was associated with inflammatory response as assessed by increased serum levels of IL-18 (Mohamed et al., 2016). A high-glucose level could also induce TLR-2 and TLR-4 expression in retinal ganglion cells via increase in the secretion of pro-inflammatory factors in diabetic retinopathy (Zhao et al., 2016).

\section{Negative feedback regulators of TLRs}

In TLR signaling, several negative regulators that function to prevent ligand-receptor binding, degrade the target protein, and inhibit recruitment or transcription of intermediates have been identified (Yuk \& Jo, 2011). Soluble forms of TLRs (sTLRs) play a central role in the regulation of inflammation in various conditions. They include soluble forms of TLR2 and TLR4 that function as a feedback 
mechanism for the inhibition of excessive TLR activation. The sTLR4 significantly inhibits LPS-mediated TNF- $\alpha$ production and NF- $\mathrm{kB}$ activation (Iwami et al., 2000). The sTLR2 inhibits bacterial lipopeptide-induced IL-8 and TNF production (LeBouder et al., 2003). Both membranebound receptors suppression of tumorigenicity $2 \mathrm{~L}$ (ST2L) and single immunoglobulin interleukin-1 receptor-related protein (SIGIRR) are membrane-associated TLR regulators. ST2L binds to the MyD88 and MAL, whereas SIGIRR binds to TLR4, IRAK4, and TRAF6. Both of them inhibit MyD88-dependent pathway (Brint et al., 2004). Other intracellular TLR regulators which include sMyD88, A20, and small heterodimer partner (SHP) have been shown to negatively regulate TLR signaling. sMyD88 substitutes MyD88 to antagonize MyD88-dependent pathway via inhibition of IRAK4 recruitment; IRAKM inhibits IRAK1 phosphorylation by targeting IRAK1-IRAK4 complex (Kobayashi et al., 2012); A20 is an inducible deubiquitination enzyme and de-ubiquitinylates TRAF6 to terminate TLR signaling (Boone et al., 2014); SHP functions as both a repressor of NF- $\mathrm{kB}$ and an inhibitor of TRAF6 ubiquitination (Leavy, 2011).

\section{Targeting of TLR signaling}

Although TLRs are essential elements in innate immune system and play a critical role in the host-defensive mechanism against microbes, overactivation of TLRs disrupts the immune homeostasis leading to excessive proinflammatory cytokines production that is no doubt involved in the pathogenesis of many autoimmune and inflammatory diseases. Thus, inhibition of TLR signaling pathways has been predicted to be an effective therapeutic strategy to suppress unwanted, disease-associated inflammatory responses (Gao et al., 2017).

In general, TLR inhibition can be achieved by two major strategies:

- Blocking the binding of TLR ligands to the receptor.

- Interfering the intracellular signaling pathways to stop the signal transduction.

Some clinical trials suggest that therapeutic manipulation of TLR pathways may offer novel means of reversing chronic liver diseases (Kesar \& Odin, 2014). In SLE, TLR7 deletion can be used as novel way to improve disease symptoms of patients with SLE because the levels of autoantibodies and inflammatory cytokines, such as IL-6 and INF- $\alpha$, will decrease (Kono et al., 2009). Accordingly, various therapeutic agents for inhibiting TLR signaling have been developed to control excessive inflammation; they can be classified as small molecule inhibitors, antibodies, oligonucleotides, lipid-A analogs, microRNAs, and new emerging nano-inhibitors (Gao et al., 2017).

\section{Small molecule inhibitors (SMIs)}

They are synthetic or naturally derived chemical weak bases that can inhibit TLR signaling by accumulation in the acidic intracellular compartments like endosomes and lysosomes leading to suppression of auto antigen presentation, blockade of endosomal TLR7, 8, and 9 signaling, and decrease in cytokine production (Kuznik et al., 2011). They include antimalarial drugs such as SM934, CpG-52364, hydroxychloroquine sulfate (HCQ), and chloroquine (CQ) that have been used to treat autoimmune diseases (RA and SLE) (Wu et al., 2016). While HCQ has been found to ameliorate hypertension and aortic endothelial dysfunction (GomezGuzman et al., 2014), CpG-52364 is more therapeutically effective and has less side effects than HCQ in SLE animal studies (Lipford et al., 2017). CQ has shown to treat various viral infections such as HIV, influenza, and dengue (Borges et al., 2013), reduce the risk of severe sepsis-induced acute renal failure (Yasuda et al., 2018), and can significantly improve the cerebral ischemia symptoms in a rat model, which suggests that it could be beneficial for patients with cardiovascular diseases (Cui et al., 2013). In addition to endosomal TLR signaling, TLR2 and 4 are other two major targets of therapeutic SMIs. TAK-242 is an anti-sepsis SMI that targets TLR4 signaling pathways via binding to cysteine 747 in the intracellular TIR domain of TLR4, which blocks the interaction between TLR4 and the adaptor proteins, thereby diminishing LPS-induced TLR4 signaling and inflammation (Matsunaga et al., 2011). Like antimalarial drugs, angiotensin II receptor blockers (ARBs) and statins have shown to inhibit Pam3CSK4 and LPS induced-TLR2 and TLR4 signaling (Fang et al., 2014).

\section{Antibodies}

They are designed to block the binding of ligands to the specific TLRs. Blockade of TLR2 and 4 signaling by antagonistic antibodies decreases disease severity in sepsis models of Gram-positive and Gram-negative bacteria (Daubeuf et al., 2007). OPN-305, an anti-TLR2 antibody, has shown to block TLR2-mediated pro-inflammatory cytokine production in vitro and in ischemia-reperfusion (IR) injury animal models (Arslan et al., 2012). T2.5, another monoclonal antiTLR2 antibody, was found to increase animal survival and protect against severe shock-like syndrome in a mouse model challenged with Pam3CSK4 or lethally challenged with Bacillus subtilis (Meng et al., 2004), decrease neural death and inflammatory responses in a model of transient brain ischemia (Ziegler et al., 2011), and prevent angiotensin II-induced cardiac fibrosis through suppressing macrophage recruitment and inflammation in the heart (Wang et al., 2011). NI-0101, an anti-TLR4 antibody, can inhibit TLR4 signaling by blocking TLR4 dimerization (Monnet et al., 2015). It could successfully block cytokine release ex vivo and in vivo, prevent LPS-induced flu-like symptoms (Monnet et al., 2017), and block synovial fluids-induced pro- 
inflammatory cytokine production in monocytes isolated from RA patients (Hatterer et al., 2016). 1A6, another TLR4-antibody, has shown to target TLR4 activation (Spiller et al., 2008), ameliorate inflammation, and prevent the disease progression in a mouse model of colitis and protect against microbial-induced septic shock in vivo (Lima et al., 2015).

\section{Oligonucleotides}

They can interfere the binding of ligands to endosomal TLRs and hence block the TLR signal transduction. Accordingly, many of them have been developed particularly to treat inflammatory diseases associated with endosomal TLR activation, such as SLE (Barrat et al., 2005). Recently, it was revealed that targeting of TLR7 and 9 signaling could be a novel strategy for treating the chronic inflammatory process associated with myasthenia gravis, an autoimmune neuromuscular disease (Cavalcante et al., 2018). IRS954, an immunoregulatory DNA sequence, has shown to antagonize TLR7/TLR9 (Guiducci et al., 2010). DV-1179, another TLR7/9 dual antagonist, was used for its safety in patients with SLE http://investors.dynavax.com/releasedetail.cfm?releaseid= 885172]. Varied forms of IMO, an immune modulatory oligonucleotide, could significantly reduce the expression of inflammatory genes in a mouse model of IL-23induced psoriasis (Suarez-Farinas et al., 2013) and inhibit the activity of TLR7, 8, and 9 signaling in SLE (Zhu et al., 2012). The inhibitory oligonucleotide (IHN-ODN) 2088, a potent TLR9 antagonist, has shown to reduce systolic blood pressure in hypertensive rats (Rommler et al., 2015). INH-ODN-24888 was designed for its promising therapeutic effect in SLE through the suppression of both TLR7 and TLR9 ().

\section{Lipid A analogs}

They are a special group of TLR antagonists, specifically targeting TLR4. The most exciting one is eritoran, which prevents the binding of LPS to TLR4 in severe sepsis patients (Opal et al., 2013). It could reduce LPS-induced NF- $\kappa B$ activation and pro-inflammatory cytokine production (TNF- $\alpha$, IL-1 $\beta$, IL-6, and IL-8) in vitro and in sepsis animal models (Barochia et al., 2011).

\section{MicroRNA inhibitors (miRNAs)}

They are small, endogenous non-coding RNAs with post-transcriptional regulatory functions to fine-tune gene expression (Bartel, 2012). About 20 miRNAs are identified to be involved in the regulation of TLR signaling pathways (He et al., 2014). Among them, miR146a, miR-155, and miR-21 are the three miRNAs that received extensive attention for their regulatory roles in TLR signaling and autoimmune diseases (Shen et al., 2016).

\section{New emerging nano-inhibitors}

They are emerging as a new class of potent TLR inhibitors that can target a single or multiple TLR pathways (Blanco et al., 2015). The lipid-conjugated non-anticoagulant heparin nanoparticle (NAHNP) is an interesting nano-inhibitor (Babazada et al., 2014a). This nanoparticle (NP) inhibitor was found to suppress LPS-induced MyD88-dependent NF- $\mathrm{kB}$ activation and inhibit subsequent cytokines production in mouse macrophages (Babazada et al., 2014b). The high-density lipoprotein (HDL)-like nanoparticle (HDL-like $\mathrm{NP}$ ) was developed as a TLR4 antagonist by sequestering LPS (Foit \& Thaxton, 2016) and has been applied to reduce LPS-induced inflammation in vivo (Guo et al., 2013). Gold nanoparticles (GNPs) have caught much attention in nanomedicine (Pedrosa et al., 2015). A bare GNP was applied as the post-treatment topically to ameliorate LPS-induced eye inflammatory responses through downregulating TLR4 expression and the corresponding LPS-induced NF- $\mathrm{kB}$ activation (Pereira et al., 2012). In another study, a cationic glycolipid-coated GNP system was developed as a new TLR4 antagonist (Rodriguez Lavado et al., 2014). The majority of TLR nano-inhibitors act on TLR4 signaling, except the peptide-GNP, P12, which has shown inhibitory activity on multiple TLRs, i.e., it not only suppressed TLR4 signaling, but also inhibited TLR2, TLR3, and TLR5 pathways (Dagvadorj et al., 2015). Further studies conferred the antiinflammatory activity of P12 in LPS-induced gene expressions, reducing the subsequent pro-inflammatory cytokine production (IL-12 and IFN- $\gamma$ ) and increasing the antiinflammatory cytokine IL-1RA (Yang et al., 2016).

\section{Egyptian studies}

All researches done till now, in Egypt, have focused on the implications of TLRs in several diseases. It was demonstrated that the genetic polymorphisms of TLR2 and TLR4 were not associated with asthma and allergic rhinitis, but significant association was found between these genetic variants and the disease severity in children (Hussein et al., 2012). It was revealed that TLR2 and TLR4 polymorphisms have no influence in HCV among Egyptian children (Soliman et al., 2014), while TLR4 polymorphism may be important predictor for $\mathrm{HCV}$ therapy in adults (Sadik et al., 2015). There was no significant association between TLR4 polymorphism and colorectal cancer (CRC), but higher serum level of it was associated with a diagnostic prospect in CRC patients (Bassuny, 2017). In addition, TLR4 was not engaged in the progression of lower respiratory tract infection in children (Allam \& Abd EL-Salam M, Mohammad A, Aboulkhair AG., 2015) but considered as a common contributor in patients with pulmonary fibrosis and lung cancer (Ahmed et al., 2016). TLR4 levels were higher in T2DM patients and found to correlate well with the severity of albuminuria suggesting its possible role in the 
pathogenesis of diabetic nephropathy (Fathy et al., 2016). Increased TLR4 expression on T cells which associated with increased reactive oxygen species (ROS) generation has been shown to play pathogenic role in autistic children (Nadeem et al., 2017).

\section{Conclusion}

Based on the existing scientific literature, it is concluded that TLRs are the main elements in the innate orchestration of immune system. Working in TLRs area including their characterization, expression, ligands recognition, signaling, and implication in many diseases has significantly progressed in past years. Our main concern should be focused on maintaining TLRs functioning and keeping the integrity of innate immune system. Targeting of TLR signaling represents a new challenge for treatment of many diseases.

\section{Abbreviations}

AP-1: Activator protein 1; ARBs: Angiotensin II receptor blockers; CpG DNA: Unmethylated CpG DNA motif; CQ: Chloroquine; CRC: Colorectal cancer; CXCL8: C-X-C motif chemokine ligand 8 or other numbers; DAMPs: Damage-associated molecular patterns; DCs: Dendritic cells; dsRNA: Double-stranded RNA; ER: Endoplasmic reticulum; GNPs: Gold nanoparticles; HBV: Hepatitis B virus; HCQ: Hydroxychloroquine sulfate; HCV: Hepatitis C virus; HDL: High-density lipoprotein; HIV: Human immunodeficiency virus; HMGB1: High-mobility group box protein 1; HSPs: Heat shock proteins; IL-1: Interlukin-1 or other numbers; IFNa: Interferon-alpha or other symbols; IRAK1: Interleukin-1 receptor-associated kinase 1 and other numbers or symbols; IR: Ischemia-reperfusion; LAM: Lipoarabinomannan; LPS: Lipopolysaccharides; LRR: Leucine-rich repeats; LTA: Lipoteichoic acid; miRNAs: MicroRNA inhibitors; mtDNA: Mitochondrial DNA; MyD88: Myeloid differentiation primaryresponse protein 88; MAPK: Mitogen-activated protein kinase; NAHNP: Nonanticoagulant heparin nanoparticle; NF-kB: Nuclear factor kappa-B; NK: Natural killer cells; NP: Nanoparticle; PAMPs: Pathogen-associated molecular patterns; PGN: Peptidoglycan; PRRs: Pattern recognition receptors; RA: Rheumatoid arthritis; ROS: Reactive oxygen species; SARM: Sterile a- and armadillo-motif-containing protein; SHP: Small heterodimer partner; SIGIRR: Single immunoglobulin interleukin-1 receptor-related protein SLE: Systemic lupus erythematous; SMls: Small molecule inhibitors; ssRNA: Single-strand RNA; sTLRs: Soluble forms of TLRs; sFFAs: Saturated free fatty acids; ST2L: Suppression of tumorigenicity; TAB2: TGF-beta activated kinase 1 (MAP3K7) binding protein 2; T2DM: Type 2 diabetes mellitus; TIRAP or MAL: TIR-domain-containing adaptor protein; TIR: Toll/interleukin-1 (IL-1) receptor domain; TLRs: Toll-like receptors; TLR1: Toll-like receptor 1 or other numbers; TNF-a: Tumor necrosis factor alpha; TRAF6: TNF-receptor-associated factor 6; TRAM: TRIF-related adaptor molecule; TRIF: TIR-domain-containing adaptor protein inducing IFN- $\beta$; VLDL: Very low density lipoprotein

\section{Acknowledgements}

The authors would like to thank National Research Centre where they work.

\section{Authors' contributions}

SREZ collected the scientific material and wrote the whole manuscript. HS participated in the scientific material collection and reviewed the whole manuscript. FAM reviewed the whole manuscript. All authors read and approved the final manuscript.

\section{Funding}

Not applicable

Availability of data and materials Not applicable
Ethics approval and consent to participate

Not applicable

\section{Consent for publication}

Not applicable

\section{Competing interests}

The authors declare that they have no competing interests.

Received: 1 November 2018 Accepted: 7 November 2019

Published online: 12 December 2019

\section{References}

Ahmad R, Al-Mass A, Atizado V, Al-Hubail A, Al-Ghimlas F, Bennakhi A, Dermime S, Behbehani K (2012) Elevated expression of the toll like receptors 2 and 4 in obese individuals: its significance for obesity-induced inflammation. Inflamm 9:48

Ahmed S, Moawad M, Elhefny R, Abdullatif M (2016) Is toll like receptor 4 a common pathway hypothesis for development of lung cancer and idiopathic pulmonary fibrosis? Egypt J Chest Dis Tuberc 65(1):289-294

Akira S, Takeda K (2004) Toll-like receptor signaling. Nat Rev Immunol 4:499-511. https://doi.org/10.1038/nri1391

Akira S, Uematsu S, Takeuchi O (2006) Pathogen recognition and innate immunity. Cell 124:783-801

Allam HA, Abd EL-Salam M, Mohammad A, Aboulkhair AG (2015) Clinical value of Toll like receptor 4 and CD14 in children with acute lower respiratory tract infection. Int Biol Biomed J Summer 1(3):90-97

Anderson KV, Bokla L, Nusslein-Volhard C (1985) Establishment of dorsal ventral polarity in the Drosophila embryo: the induction of polarity by the Toll gene product. Cell 42:791-798

Arslan F, Houtgraaf JH, Keogh B, Kazemi K, de Jong R (2012) Treatment with OPN-305, a humanized anti-Toll-like receptor-2 antibody, reduces myocardial ischemia/reperfusion injury in pigs. Circ Cardiovasc Interv 5:279-287. https:// doi.org/10.1161/CIRCINTERVENTIONS.111.967596

Ayres JS, Schneider DS (2012) Tolerance of infections. Annu Rev Immunol 30: 271-294

Babazada H, Yamashita F, Hashida M (2014a) Suppression of experimental arthritis with self-assembling glycol-split heparin nanoparticles via inhibition of TLR4-NF-kappaB signaling. J Control Release 194:295-300. https://doi.org/ 10.1016/j.jconrel.2014.09.015

Babazada H, Yamashita F, Yanamoto S, Hashida M (2014b) Self-assembling lipid modified glycol-split heparin nanoparticles suppress lipopolysaccharideinduced inflammation through TLR4-NF-kappaB signaling. J Control Release 194:332-340. https://doi.org/10.1016/j.jconrel.2014.09.011

Barochia A, Solomon S, Cui X, Natanson C, Eichacker PQ (2011) Eritoran tetrasodium (E5564) treatment for sepsis: review of preclinical and clinical studies. Drug Metab Toxicol 7:479-494. https://doi.org/10.1517/17425255. 2011.558190

Barrat FJ, Meeker T, Gregorio J, Chan JH, Uematsu S, Akira S (2005) Nucleic acids of mammalian origin can act as endogenous ligands for Toll-like receptors and may promote systemic lupus erythematosus. J Exp Med 202:1131-1139. https://doi.org/10.1084/jem.20050914

Bartel DP (2012) MicroRNAs: target recognition and regulatory functions. Cell 136: 215-233. https://doi.org/10.1016/j.cell.2009.01.002

Bassuny YMN. Study of single nucleotide polymorphisms in TLR4 and NOD2 in Egyptian patients with colorectal cancer. MD. Cairo: Cairo University; faculty of pharmacy. Available from: http://erepository.cu.edu.eg/index.php/ cutheses/article/view/7601. 2017.

Bernard NJ, O'Neill LA (2013) Mal, more than a bridge to MyD88. IUBMB Life 65: 777-786

Blanco E, Shen H, Ferrari M (2015) Principles of nanoparticle design for overcoming biological barriers to drug delivery. Nat Biotechnol 33:941-951. https://doi.org/10.1038/nbt.3330

Blasius AL, Beutler B (2010) Intracellular toll-like receptors. Immunity 32(3):305315. https://doi.org/10.1016/j.immuni.2010.03.012

Boone DL, Turer EE, Lee EG, Ahmad RC, Wheeler MT, Tsui C (2014) The ubiquitinmodifying enzyme A20 is required for termination of Toll-like receptor responses. Nat Immunol 5:1052-1060

Borges MC, Castro LA, Fonseca BA (2013) Chloroquine use improves denguerelated symptoms. Mem Inst Oswaldo Cruz. 108:596-599. https://doi.org/10. 1590/S0074-02762013000500010 
Bresnahan KA, Tanumihardjo SA (2014) Undernutrition, the acute phase response to infection, and its effects on micronutrient status indicators. Adv Nutr 5(6): 702-711 https://doi.org/10.3945/an.114.006361

Brikos C, O'Neill LAJ. Signaling of Toll-like receptors and innate immunity 22-41. Handbook of Experimental Pharmacology, Volume 183 Stefan Bauer Gunther Hartmann (eds). 2008.

Brint EK, Xu D, Liu H, Dunne A, McKenzie AN, O'Neill LA (2004) ST2 is an inhibitor of interleukin 1 receptor and Toll-like receptor 4 signaling and maintains endotoxin tolerance. Nat Immunol 5:373-379

Bryant CE, Symmons M, Gay NJ (2015) Toll-like receptor signaling through macromolecular protein complexes. Mol Immunol 63:162-165

Burns K, Janssens S, Vercammen E, Tschopp J (2003) Inhibition of interleukin 1 receptor/Toll-like receptor signaling through the alternatively spliced, short form of MyD88 is due to its failure to recruit IRAK-4. J Exp Med 197:263-268

Cavalcante P, Barzago C, Baggi F, Antozzi C, Maggi L, Mantegazza R, Bernasconi P (2018) Toll-like receptors 7 and 9 in myasthenia gravis thymus: amplifiers of autoimmunity? Ann N Y Acad Sci 1413(1):11-24. https:/doi.org/10.1111/nyas.13534

Cole JE, Georgiou E, Monaco C (2010) The expression and functions of toll-like receptors in atherosclerosis. Mediators Inflamm 393946

Couillault C, Pujol N, Reboul J, Sabatier L, Guichou JF, Kohara Y, Ewbank JJ (2004) TLR-independent control of innate immunity in Caenorhabditis elegans by the TIR domain adaptor protein TIR-1, an ortholog of human SARM. Nature Immunol 5:488-494

Cui G, Ye X, Zuo T, Zhao H, Zhao Q, Chen W (2013) Chloroquine pretreatment inhibits toll-like receptor 3 signaling after stroke. Neurosci Lett 548:101-104. https://doi.org/10.1016/j.neulet.2013.02.072

Cusson-Hermance N, Khurana S, Lee TH, Fitzgerald KA, Kelliher MA (2005) RIP1 mediates the TRIF-dependent Toll-like receptor 3- and 4-induced NF-KB activation but does not contribute to interferon regulatory factor 3 activation. J Biol Chem 280:36560-36566

Dagvadorj J, Shimada K, Chen S, Jones HD, Tumurkhuu G, Zhang W (2015) Lipopolysaccharide induces alveolar macrophage necrosis via CD14 and the P2X7 receptor leading to interleukin-1a release. Immunity 42:640-653. https://doi.org/10.1016/j.immuni.2015.03.007

Daubeuf B, Mathison J, Spiller S, Hugues S, Herren S, Ferlin W (2007) TLR4/MD-2 monoclonal antibody therapy affords protection in experimental models of septic shock. J Immunol 179:6107-6114. https://doi.org/10.4049/jimmunol. 179.9.6107

Delneste Y, Beauvillain C, Jeannin P (2007) Innate immunity: structure and function of TLRs. Med Sci (Paris) 23(1):67-73. https://doi.org/10.1051/medsci/ 200723167

Devaraj S, Yun JM, Duncan Staley CR, Jialal I (2011) Low vitamin D levels correlate with the proinflammatory state in type 1 diabetic subjects with and without microvascular complications. Am J Clin Pathol 135:429-433

Do JE, Kwon SY, Park S, Lee ES (2008) Effects of vitamin D on expression of tolllike receptors of monocytes from patients with Behcet's disease. Rheumatol Oxf Engl 47:840-848

Dolasia K, Bisht MK, Pradhan G, Udgata A, Mukhopadhyay S. TLRs/NLRs: shaping the landscape of host immunity. Int Rev Immunol. 2018. 37(1): 3-19. doi.org/ https://doi.org/10.1080/08830185.2017.1397656.

Donath MY, Shoelson SE, Kim JJ (2011) Type 2 diabetes as an inflammatory disease. Nat Rev Immunol 11:98-107

Fang D, Yang S, Quan W, Jia H, Quan Z, Qu Z (2014) Atorvastatin suppresses tolllike receptor 4 expression and NF-KB activation in rabbit atherosclerotic plaques. Eur Rev Med Pharmacol Sci 18:242-246

Fathy WM, Soliman MA, Ragheb A, Al-Ashram GH. Study of toll-like receptor 4 in type 2 diabetic patients with or without nephropathy. Menoufia Medical Journal J. 2016. 29 (1): 167-173.

Foit L, Thaxton CS (2016) Synthetic high-density lipoprotein-like nanoparticles potently inhibit cell signaling and production of inflammatory mediators induced by lipopolysaccharide binding Toll-like receptor 4. Biomaterials 100 67-75. https://doi.org/10.1016/j.biomaterials.2016.05.021

Gao W, Xiong Y, Li Q, Yang H (2017) Inhibition of Toll-like receptor signaling as a promising therapy for inflammatory diseases: a journey from molecular to nano therapeutics. Front Physiol 8:508-517. https://doi.org/10.3389/fphys. 2017.00508

Gauthier MEA, Du Pasquier L, Degnan BM (2010) The genome of the sponge Amphimedon queenslandica provides new perspective into the origin of Tolllike and interleukin 1 pathways. Evol Dev 12:519-533

Gay NJ, Symmons MF, Gangloff M, Bryant CE (2014) Assembly and localization of Toll-like receptor signalling complexes. Nat Rev Immunol 14:546-558
Golshiri-Isfahani A, Amizadeh M, Arababadi MK (2018) The roles of toll like receptor 3,7 and 8 in allergic rhinitis pathogenesis. Allergol Immunopathol S0301-0546(17):30186-30186. https://doi.org/10.1016/j.aller.2017.09.026

Gomez-Guzman M, Jimenez R, Romero M, Sanchez M, Zarzuelo MJ, GomezMorales M (2014) Chronic hydroxychloroquine improves endothelial dysfunction and protects kidney in a mouse model of systemic lupus erythematosus. Hypertension 64:330-337. https://doi.org/10.1161/114.03587

Goulopoulou S, McCarthy CG, Webb RC (2016) Toll-like receptors in the vascular system: sensing the dangers within. Pharmacol Rev 68(1):142-167. https:// doi.org/10.1124/pr.114.010090

Guiducci C, Gong M, Xu Z, Gill M, Chaussabel D, Meeker T (2010) TLR recognition of self-nucleic acids hampers glucocorticoid activity in lupus. Nature 465: 937-941. https://doi.org/10.1038/nature09102

Guo L, Ai J, Zheng Z, Howatt DA, Daugherty A, Huang B (2013) High density lipoprotein protects against polymicrobe-induced sepsis in mice. J Biol Chem 288:17947-17953. https://doi.org/10.1074/jbc.M112.442699

Hatterer E, Shang L, Simonet P, Herren S, Daubeuf B, Teixeira S (2016) A specific anti-citrullinated protein antibody profile identifies a group of rheumatoid arthritis patients with a toll-like receptor 4-mediated disease. Arthritis Res Ther 18:224. https://doi.org/10.1186/s13075-016-1128-5

He X, Jing Z, Cheng G (2014) MicroRNAs: new regulators of Toll-like receptor signalling pathways. Biomed Res Int 945169. https://doi.org/10.1155/2014/ 945169

Heijden IM, Wilbrink B, Tchetverikov I (1998) Presence of bacterial DNA and bacterial peptidoglycans in the joints of patients with rheumatoid arthritis and other arthritis's. Arthritis Rheum 41(9):S162

Hemmi H, Takeuchi O, Kawai T (2000) A Toll-like receptor recognizes bacterial DNA. Nature 408(6813):740-745. https://doi.org/10.1038/35047123

Hoebe K, Du X, Georgel P (2003) Identification of Lps2 as a key transducer of MyD88-independent TIR signalling. Nature 424(6950):743-748

Huang QQ, Pope RM (2009) Role of Toll like receptors in rheumatoid arthritis. Curr Rheumatol Rep. 11(5):357-364

Hussein YM, Awad HA, Shalaby SM, Ali AA, Alzahrani SS (2012) Toll-like receptor 2 and Toll-like receptor 4 polymorphisms and susceptibility to asthma and allergic rhinitis: a case-control analysis. Cellular Immunol 274(1-2):34-38

Isaza-Correa JM, Zheng Liang Z, van den Berg A, Arjan Diepstra A, Lydia VL (2014) Toll-like receptors in the pathogenesis of human B cell malignancies. J Hematol Oncol 7:57. https://doi.org/10.1186/s13045-014-0057-5

Ishibashi M, Sayers S, D'Armiento JM, Tall AR, Welch CL (2013) TLR3 deficiency protects against collagen degradation and medial destruction in murine atherosclerotic plaques. Atherosclerosis 229:52-61

Iwami Kl, Matsuguchi T, Masuda A, Kikuchi T, Musikacharoen T, Yoshikai Y (2000) Cutting edge: naturally occurring soluble form of mouse Toll-like receptor 4 inhibits lipopolysaccharide signaling. J Immunol 165:6682-6686

Jaffer U, Wade RG, Gourlay T (2010) Cytokines in the systemic inflammatory response syndrome: a review. HSR Proc Intensive Care Cardiovasc Anesth 2(3):161-175

Jialal I, Kaur H, Devaraj S (2015) Toll-like receptor status in obesity and metabolic syndrome: a translational perspective. J Clin Endocrinol Metab 99(1):39-48. https://doi.org/10.1210/jc.2013-3092

Kagan J. Signaling organelles of the innate immune system. Cell. 2012. 7; 151(6): 1168-1178. doi: https://doi.org/10.1016/j.cell.2012.11.011.

Kaiser WJ, Offermann MK (2005) Apoptosis induced by the toll-like receptor adaptor TRIF is dependent on its receptor interacting protein homotypic interaction motif. J Immunol 174(8):4942-4952

Karaali ZE, Candan G, Aktuğlu MB, Velet M, Ergen A (2019) Toll-like receptor 2 (TLR-2) gene polymorphisms in type 2 diabetes mellitus. Cell J 20(4):559-563. https://doi.org/10.22074/cellj.2019.5540

Kawai T, Akira S (2010) Toll-like receptors and their crosstalk with other innate receptors in infection and immunity. Nat Immunol 11(5):373-384. https://doi. org/10.1038/ni.1863

Kawai T, Akira S. Toll-like receptors and their crosstalk with other innate receptors in infection and immunity. Immunity. 2011. 34(5): 637-650. doi.org/https:// doi.org/10.1016/j.immuni.2011.05.006.

Kesar V, Odin JA (2014) Toll-like receptors and liver disease. Liver Int 34(2):184196. https://doi.org/10.1111/liv.12315

Kobayashi K, Hernandez LD, Galán JE, Janeway CA Jr, Medzhitov R, Flavell RA (2012) IRAK-M is a negative regulator of Toll-like receptor signaling. Cell 110:191-202

Komurcu HF, Kilic N, Demirbilek ME, Akin KO (2016) Plasma levels of vitamin B12, epidermal growth factor and tumor necrosis factor alpha in patients with Alzheimer dementia. Int J Res Med Sci 4(3):734-738 
Kono DH, Haraldsson MK, Lawson BR, Pollard KM, Koh YT, Du X (2009) Endosomal TLR signaling is required for anti-nucleic acid and rheumatoid factor autoantibodies in lupus. Proc Natl Acad Sci 106:12061-12066. https://doi.org/ 10.1073/pnas.0905441106

Kumar H, Kawai T, Akira S (2011) Pathogen recognition by the innate immune system. Int Rev Immunol 30:16-34

Kuznik A, Bencina M, Svajger U, Jeras M, Rozman B, Jerala R (2011) Mechanism of endosomal TLR inhibition by antimalarial drugs and imidazoquinolines. J Immunol 186:4794-4804. https://doi.org/10.4049/jimmunol.1000702

Lancaster Gl, Khan Q, Drysdale P, Wallace W, Jeukendrup AE, Drayson MT, Gleeson M (2005) The physiological regulation of toll-like receptor expression and function in humans. J Physiol 563(3):945-955. https://doi.org/10.1113/ jphysiol.2004.081224

Leavy O (2011) Innate immunity: SHP regulates TLR signalling. Nat Rev Immunol 11:502

LeBouder E, Rey-Nores JE, Rushmere NK, Grigorov M, Lawn SD, Affolter M (2003) Soluble forms of Toll-like receptor (TLR)2 capable of modulating TLR2 signaling are present in human plasma and breast milk. J Immunol 171: 6680-6689

Lee YH, Choi SJ, Ji JD, Song GG (2016) Association between toll-like receptor polymorphisms and systemic lupus erythematous: a meta-analysis update. Lupus 25:593-601. https://doi.org/10.1177/0961203315622823

Lemaitre B, Nicolas E, Michaut L, Reichhart JM, Hoffmann LA (1996) The dorsoventral regulatory gene cassette spätzle/Toll/cactus controls the potent antifungal response in Drosophila adults. Cell 86:973-983

Li X, Jiang S, Tapping RI (2010) Toll-like receptor signaling in cell proliferation and survival. Cytokine 49:1-9. https://doi.org/10.1016/j.cyto.2009.08.010

Lima CX, Souza DG, Amaral FA, Fagundes CT, Rodrigues IP, Alves-Filho JC (2015) Therapeutic effects of treatment with anti-TLR2 and anti-TLR4 monoclonal antibodies in polymicrobial sepsis. PLoS ONE 10:e0132336. https://doi.org/10. 1371/journal.pone.0132336

Lipford G, Forsbach A, Zepp C, Nguyen T, Weeratna R, McCluskie M. "Selective toll-like receptor 7/8/9 antagonists for the oral treatment of autoimmune diseases," in American College of Rheumatology 2007 Annual Scientific Meeting (Boston, MA). 2017.

Lu X, Xu Q, Bu X, Ma X, Zhang F, Deng Q, Zhang Y, Ding J (2014) Relationship between expression of toll-like receptors $2 / 4$ in dendritic cells and chronic hepatitis B virus infection. Int J Clin Exper Pathol 7(9):6048-6055

Lyn-Cook BD, Xie C, Oates J, Treadwell E, Word B, Hammons G (2014) Increased expression of Toll-like receptors (TLRs) 7 and 9 and other cytokines in systemic lupus erythematous (SLE) patients: ethnic differences and potential new targets for therapeutic drugs. Mol Immunol 61:38-43. https://doi.org/10. 1016/j.molimm.2014.05.001

Mahla RS (2013) Sweeten PAMPs: role of sugar complexed PAMPs in innate immunity and vaccine biology. Front Immunol 4:248. https://doi.org/10.3389/ fimmu.2013.00248

Mansell A, Brint E, Gould JA, O'Neill LA, Hertzog PJ (2004) Mal interacts with tumor necrosis factor receptor-associated factor (TRAF)- 6 to mediate NF-kB activation by Toll-like receptor (TLR)-2 and TLR4. J Biol Chem 279:3722737230

Matsunaga N, Tsuchimori N, Matsumoto T, li M (2011) TAK-242 (resatorvid), a smallmolecule inhibitor of Toll-like receptor (TLR) 4 signaling, binds selectively to TLR4 and interferes with interactions between TLR4 and its adaptor molecules Mol Pharmacol 79:34-41. https://doi.org/10.1124/mol.110.068064

McCarthy CG, Wenceslau CF, Goulopoulou S, Ogbi S, Baban B, Sullivan JC (2015) Circulating mitochondrial DNA and Toll-like receptor 9 are associated with vascular dysfunction in spontaneously hypertensive rats. Cardiovasc Res 107: 119-130. https://doi.org/10.1093/cvr/cvv137

McGettrick AF, Brint EK, Palsson-McDermott EM, Rowe DC, Golenbock DT, Gay NJ, Fitzgerald KA, O'Neill LAJ (2006) TRIF-related adapter molecule is phosphorylated by PKC $\varepsilon$ during Toll-like receptor 4 signaling. Proc Natl Acad Sci 103:9196-9201

Medzhitov R, Preston-Hurlburt P, Janeway CA (1997) A human homologue of the Drosophila Toll protein signals activation of adaptive immunity. Nature 388 : 394-397

Meng G, Rutz M, Schiemann M, Metzger J, Grabiec A, Schwandner R (2004) Antagonistic antibody prevents toll-like receptor 2-driven lethal shock-like syndromes. J Clin Invest. 113:1473-1481. https://doi.org/10.1172/JCI20762

Mohamed ZAZ, Abd-Elraheem SE, El-Nahrery EMA, Sabry S, Mohamed MSE (2016) TLR2 and IL 18 in obese diabetic patienT. J Diabetes Metab 7:5. https://doi. org/10.4172/2155-6156.1000672
Monnet E, Lapeyre G, Poelgeest EV, Jacqmin P, Graaf K, Reijers J (2017) NI-0101, a monoclonal antibody targeting toll like receptor 4 (TLR4) being developed for rheumatoid arthritis (RA) treatment with a potential for personalized medicine. Clin Pharmacol Ther 101:200-208. https://doi.org/10.1002/cpt.522

Monnet E, Shang L, Lapeyre G, de Graaf K, Hatterer E, Buatois V (2015) Evidence of NI-0101 pharmacological activity, an anti-TLR4 antibody, in a randomized phase I dose escalation study in healthy volunteers receiving LPS. Ann Rheum Dis 74:1. https://doi.org/10.1136/annrheumdis-2015-eular.3801

Moresco EM, LaVine D, Beutler B (2011) Toll-like receptors. Curr Biol 21(13):R488R493

Murad S (2014) Toll-like receptor 4 in inflammation and angiogenesis: a doubleedged sword. Front Immunol 5:313

Nadeem A, Ahmad SF, Bakheet SA, Al-Harbi NO, Al-Ayadhi LY, Attia SM, Zoheir KMA (2017) Toll-like receptor 4 signaling is associated with upregulated NADPH oxidase expression in peripheral T cells of children with autism. Brain Behav Immun 61:146-154. https://doi.org/10.1016/j.bbi.2016.12.024

Opal SM, Laterre PF, Francois B, LaRosa SP, Angus DC, Mira JP (2013) Effect of eritoran, an antagonist of MD2-TLR4, on mortality in patients with severe sepsis: the ACCESS randomized trial. JAMA 309:1154-1162. https://doi.org/10. 1001/jama.2013.2194

Pedrosa P, Vinhas R, Fernandes A, Baptista PV (2015) Gold nanotheranostics: proof-of-concept or clinical tool? Nanomaterials 5:1853-1879. https://doi.org/ 10.3390/nano5041853

Pereira DV, Petronilho F, Pereira HR, Vuolo F, Mina F, Possato JC (2012) Effects of gold nanoparticles on endotoxin-induced uveitis in rats. Invest Ophthalmol Vis Sci 53:8036-8041. https://doi.org/10.1167/iovs.12-10743

Poltorak A, He X, Smirnova I, Liu MY, Van Huffel C, Du X (1998) Defective LPS signaling in $\mathrm{C} 3 \mathrm{H} / \mathrm{HeJ}$ and $\mathrm{C} 57 \mathrm{BL} / 10 \mathrm{ScCr}$ mice: mutations in TLR4 gene. Science 282:2085-2088

Radstake TR, Roelofs MF, Jenniskens YM, Oppers-Walgreen B, van Riel PL, Barrera $P$ (2004) Expression of toll-like receptors 2 and 4 in rheumatoid synovial tissue and regulation by pro-inflammatory cytokines interleukin-12 and interleukin-18 via interferon-gamma. Arthritis Rheum 50(12):3856-3865

Re F, Strominger JL (2011) Toll-like receptor 2 (TLR2) and TLR4 differentially activate human dendritic cells. J Biol Chem 276:37692-37699. https://doi.org/ 10.1074/jbc.M105927200

Rodriguez Lavado J, Sestito SE, Cighetti R, Aguilar Moncayo EM, Oblak A, Lainscek D (2014) Trehalose- and glucose-derived glycoamphiphiles: small-molecule and nanoparticle Toll-like receptor 4 (TLR4) modulators. J Med Chem 57: 9105-9123. https://doi.org/10.1021/jm501182w

Roelofst MF, Joosten LA, Abdollahi-Roodsaz S, van Lieshout AW, Sprong T, van den Hoogen FH (2005) The expression of toll-like receptors 3 and 7 in rheumatoid arthritis synovium is increased and costimulation of toll-like receptors 3,4 , and $7 / 8$ results in synergistic cytokine production by dendritic cells. Arthritis Rheum 52(8):2313-2322

Rommler F, Hammel M, Waldhuber A, Muller T, Jurk M, Uhlmann E (2015) Guanine-modified inhibitory oligonucleotides efficiently impair TLR7- and TLR9-mediated immune responses of human immune cells. PLOS ONE 10: e0116703. https://doi.org/10.1371/journal.pone.0116703

Sadik NA, Shaker OG, Ghanem HZ, Hassan HA, Abdel-Hamid AH (2015) Singlenucleotide polymorphism of Toll-like receptor 4 and interleukin-10 in response to interferon-based therapy in Egyptian chronic hepatitis C patients. Arch Virol. 160(9):2181-2195. https://doi.org/10.1007/s00705-015-2493-0

Schneider DS, Hudson KL, Lin TY, Anderson KV (1991) Dominant and recessive mutations define functional domains of Toll, a Trans membrane protein required for dorsal-ventral polarity in the Drosophila embryo. Genes Dev 5: 797-807

Sellge G, Kufer TA (2015) PRR-signaling pathways: learning from microbial tactics. Semin Immunol 27:75-84

Sepehri Z,Kiani Z,Nasiri AA, andKohan F. Toll-like receptor 2 and type 2 diabetes. Cell Mol Biol Lett 2016; 21: 2. doi: https://doi.org/10.1186/s11658-016-0002-4

Sharma N, Akhade AS, Qadri A (2013) Sphingosine-1-phosphate suppresses TLRinduced CXCL8 secretion from human T cells. J Leukoc Biol 93(4):521-528. https://doi.org/10.1189/jlb.0712328

Shen N, Liang D, Tang Y, de Vries N, Tak PP (2016) MicroRNAs-novel regulators of systemic lupus erythematosus pathogenesis. Nat Rev Rheumatol 8:701709. https://doi.org/10.1038/nrrheum.2012.142

Sindhu S, Akhter N, Kochumon S, Thomas R, Wilson A, Shenouda S, Tuomilehto J (2018) Increased expression of the innate immune receptor TLR10 in obesity and type-2 diabetes: association with ROS-mediated oxidative stress. Cell Physiol Biochem 45:572-590 https://doi.org/10.1159/000487034 
Singh K, Kant S, Gupta SK, Singh VK (2014) Toll-like receptor 4 polymorphisms and their haplotypes modulate the risk of developing diabetic retinopathy in type 2 diabetes patients. Mol Vision 20:704-713

So EY, Ouchi T (2010) The application of toll like receptors for cancer therapy. Int J Biol Sci 6(7):675-681

Soliman OE, Shaltout AA, Hasaneen BM, Mosaad AE, Mosaad YM (2014) Toll-like receptors genotype polymorphism in Egyptian children with chronic viral hepatitis C. Arch Dis Child 99(2):A1-A620 doi.org/10.1136/archdischild-2014-307384.294

Spiller S, Elson G, Ferstl R, Dreher S, Mueller T, Freudenberg M (2008) TLR4induced IFN-gamma production increases TLR2 sensitivity and drives Gramnegative sepsis in mice. J Exp Med 205:1747-1754. https://doi.org/10.1084/ jem.20071990

Suarez-Farinas M, Arbeit R, Jiang W, Ortenzio FS, Sullivan T, Krueger JG (2013) Suppression of molecular inflammatory pathways by Toll-like receptor 7, 8, and 9 antagonists in a model of IL-23-induced skin inflammation. PLOS ONE 8:e84634. https://doi.org/10.1371/journal.pone.0084634

Subramanian S, Tus K, Li QZ, Wang A, Tian XH, Zhou J (2006) A TLR7 translocation accelerates systemic autoimmunity in murine lupus. Proc Natl Acad Sci USA 103:9970-9975. https://doi.org/10.1073/pnas.0603912103

Takeda K, Akira S. Toll-like receptors. In: Coligan John E, et al., editors. Current protocols in immunology. 2015. 109: 1421-20.

Takeda K, Georgel P, Janssen E (2004) Toll like receptor and their ligands. Proc Natl Acad Sci 101(10):3516-3521. https://doi.org/10.1073/pnas.040052510

Troutman TD, Hu W, Fulenchek S, Yamazaki T, Kurosaki T, Bazan JF (2012) Role for B-cell adapter for PI3K (BCAP) as a signaling adapter linking Toll-like receptors (TLRs) to serine/threonine kinases PI3K/Akt. Proc Natl Acad Sci 109: 273-278

Tsujimoto H, Ono S, Efron PA, Scumpia PO, Moldawer LL, Mochizuki H (2008) Role of Toll-like receptors in the development of sepsis. Shock 29(3):315-321. https://doi.org/10.1097/SHK.0b013e318157ee55

Vidya MK, Kumar VG, Sejian V, Bagath M, Krishnan G, Bhatta R (2017) Toll-like receptors: significance, ligands, signaling pathways, and functions in mammals. Int Rev Immunol 37(3):1-17 doi.org/10.1080/08830185.2017.1380200

Wang $Y$, Song E, Bai B, Vanhoutte PM. Toll-like receptors mediating vascular malfunction: lessons from receptor subtypes. Pharm \& Therap 2015. In press. doi.org/10.1016/j.pharmthera.2015.12.005

Wang YC, Lin S, Yang QW (2011) Toll-like receptors in cerebral ischemic inflammatory injury. J Neuroinflammation 8:134. https://doi.org/10.1186/ 1742-2094-8-134

Wong SW, Kwon MJ, Choi AM, Kim HP, Nakahira K, Hwang DH (2009) Fatty acids modulate toll-like receptor 4 activation through regulation of receptor dimerization and recruitment into lipid rafts in a reactive oxygen speciesdependent manner. J Biol Chem 284:27384-27392

Wu Y, He S, Bai B, Zhang L, Xue L, Lin Z (2016) Therapeutic effects of the artemisinin analog SM934 on lupus-prone MRL/Ipr mice via inhibition of TLRtriggered B-cell activation and plasma cell formation. Cell Mol Immunol 13: 379-390. https://doi.org/10.1038/cmi.2015.13

Yamamoto M, Sato S, Hemmi H, Sanjo H, Uematsu S, Kaisho T (2002) Cutting edge: a novel Toll/IL-1 receptor domain-containing adaptor that preferentially activates the IFN-beta promoter in the Toll-like receptor signaling. J Immunol 169(12):6668-6672

Yamamoto M, Takeda K (2010) Current views of toll-like receptor signaling pathways. Gastroenterol Res Pract 240365. https://doi.org/10.1155/2010/240365

Yang H, Kozicky L, Saferali A, Fung SY, Afacan N, Cai B (2016) Endosomal pH modulation by peptide-gold nanoparticle hybrids enables potent antiinflammatory activity in phagocytic immune cells. Biomaterials 111:90-102 doi.org/10.1016/j.biomaterials.2016.09.032

Yasuda H, Leelahavanichkul A, Tsunoda S, Dear JW, Takahashi Y, Ito S (2018) Chloroquine and inhibition of Toll-like receptor 9 protect from sepsisinduced acute kidney injury. Am J Physiol Renal Physiol 294:F1050-F1058. https://doi.org/10.1152/ajprenal.00461.2007

Yin J, Peng Y, Wu J, Wang Y, Yao L (2014) Toll-like receptor 2/4 links to free fatty acid-induced inflammation and beta-cell dysfunction. J Leukoc Biol 95:47-52

Yu L, Feng Z (2018) The role of toll-like receptor signalling in the progression of heart failure. Mediators Inflamm 8:9874109. https://doi.org/10.1155/2018/ 9874109

Yuk JM, Jo EK (2011) Toll-like receptors and innate immunity. J Bacteriol Virol 41(4):225-235

Zarember KA, Godowski PJ (2002) Tissue expression of human Toll-like receptors and differential regulation of Toll-like receptor mRNAs in leukocytes in response to microbes, their products, and cytokines. J Immunol 168(2):554-561
Zhang Y, Liang C (2016) Innate recognition of microbial-derived signals in immunity and inflammation. Sci China Life Sci 59(12):1210-1217. https:/doi. org/10.1007/s11427-016-0325-6

Zhang YW, Thompson R, Zhang H, Xu H (2011) APP processing in Alzheimer's disease. Mol Brain 4:3-11. https://doi.org/10.1186/1756-6606-4-3

Zhao GN, Jiang DS, Li HL. Interferon regulatory factors: at the crossroads of immunity, metabolism, and disease. Biochimica et Biophysica Acta. 2015. 1852(2): 365 378. doi.org/https://doi.org/10.1016/j.bbadis.2014.04.030.

Zhao M, Li CH, Liu YL (2016) Toll-like receptor (TLR)-2/4 expression in retinal ganglion cells in a high-glucose environment and its implications. Genet $\mathrm{Mol}$ Res 15(2):23-41

Zhu F, Jiang W, Dong Y, Kandimalla E, La Monica N, Agrawal S (2012) IMO-8400, a novel TLR7, TLR8 and TLR9 antagonist, inhibits disease development in lupus-prone NZBW/F1 mice. J Immunol 188(1):109-112

Ziegler G, Freyer D, Harhausen D, Khojasteh U, Nietfeld W, Trendelenburg G (2011) Blocking TLR2 in vivo protects against accumulation of inflammatory cells and neuronal injury in experimental stroke. J Cereb Blood Flow Metab 31:757-766. https://doi.org/10.1038/jcbfm.2010.161

\section{Publisher's Note}

Springer Nature remains neutral with regard to jurisdictional claims in published maps and institutional affiliations.

\section{Submit your manuscript to a SpringerOpen ${ }^{\circ}$ journal and benefit from:}

- Convenient online submission

- Rigorous peer review

- Open access: articles freely available online

- High visibility within the field

- Retaining the copyright to your article

Submit your next manuscript at $>$ springeropen.com 